\title{
Homosexuality in Ghana
}

\author{
I. D. Norman, B. Awiah, F. A. Norvivor, J. Komesuor, M. Kweku, F. N. Binka \\ School of Public Health, University of Health and Allied Sciences, Ho, Ghana \\ Email: ishmael_norman@yahoo.com
}

Received 21 November 2015; accepted 15 January 2016; published 20 January 2016

Copyright (C) 2016 by authors and Scientific Research Publishing Inc.

This work is licensed under the Creative Commons Attribution International License (CC BY).

http://creativecommons.org/licenses/by/4.0/

(c) (i) Open Access

\begin{abstract}
Although homosexuality is a crime in Ghana, like many others in Africa, it is practiced in both the provincial towns and communities and in the major urban centres. Generally the society is reticent about discussing sex, yet the national society is as over-sexualized as those societies that openly discuss sex. This paper investigated the incidence and prevalence of homosexuality and lesbianism in Ghana. Assessment was done on association among psychosocial background, sexual attitudes and homosexuality, including the use of paraphernalia in the sexual lives of the people. This cross-sectional study consisted of questionnaire survey and documentary review on the internet. Respondents completed self-administered and anonymous survey with open-ended question about their sexuality and sexual preferences. The sample consisted of $N=1068$ respondents. Sampling selection was of random, pre-stratified by gender and region, which was based on the population survey by the Ghana Statistical Service for 2009. We found that the national attitudes towards homosexuality in general were changing from ambivalence to focused activism and agitation against homosexuality on one hand and acceptance on the other hand. Homosexuality and lesbian practices are prevalent in all socio-economic classes and ages of society. The study revealed that pornography and other sex media were accepted as part of the sexual repertoire of Ghanaian society. The societal reticence about sexuality that exists among the population tends to distort sexual beliefs, and imposes fear and dishonesty in sexual identification. This situation may complicate interventions for sexually transmitted diseases, as well as sexual or mental health.
\end{abstract}

\section{Keywords}

Homosexuality, Bisexuality, Lesbianism, Homophobia, Ghana

\section{Introduction}

The predominant sexual group in Ghana is those who describe themselves as heterosexual. It is fair to think that homosexual and bisexual as well as transgender sexual individuals are also present in Ghana although this in-

How to cite this paper: Norman, I. D., Awiah, B., Norvivor, F. A., Komesuor, J., Kweku, M., \& Binka, F. N. (2016). Homosexuality in Ghana. Advances in Applied Sociology, 6, 12-27. http://dx.doi.org/10.4236/aasoci.2016.61002 
vestigation is about homosexuality in both men and women (Appiah, 2006). The anti-homosexual sentiments have moved from total ambivalence to sustained interests and agitation to condemnation of the practice by men and women of different religious and moral proclivities. Several studies maintain that those who exhibit negative sexual attitudes to male homosexuality are more likely to be religious and attend church frequently. They also tend to follow conservative religious dogma and ideology (Alston, 1974; Nyberg \& Alston, 1976; Cameron \& Ross, 1981; Herek, 1984; Bhugra, 2010). It is argued that the negative reaction towards male homosexuality is a defensive mechanism by the perpetrator to reinforce masculine stereotypes (Black \& Stevenson, 1984). The national homophobia stretches from university professors, lecturers, and students, to the clergy, government ministers and their respective bureaucracies, and the average person. It has also been reported that homophobic individuals are described as status-conscious, anal retentive, authoritarian, sexually-rigid persons, who see homosexuals as sick people (Kan et al., 2009; Smith, 1987; Bleek, 1976; Lumby, 1976; Osei, 2011). Those who have positive attitudes towards homosexual are more likely to have personal contact with homosexuals (Milham et al., 1976; Glassner \& Owen, 1979; Bowman, 1979).

Apart from the clergy and other people similarly situated, many in the medical community also take a hostile attitude towards homosexuality. Such negativity also affects the health concerns of homosexuals. Due to homophobic tendencies among the medical profession, concerns have been raised about the health and treatment of homosexuals in many jurisdictions, where homosexuals are reticent about disclosing sexuality (Rose, 1994; McFarlane, 1998; Parker \& Bhugra, 2000). Communication about sexuality between patients and doctors is strained or self-censored in the face of HIV and AIDS and associated high risk behaviours such as men who have sex with men and other practices such as anal sex between men and women, which are part of the repertoire of both heterosexuality and homosexuality (Rose, 1994; Valleroy et al., 2000; Hinchliff, Gott, \& Galena, 2005; Adams, McCreanor, \& Braun, 2008; Kan et al., 2009; Biaya, 1999).

The Consolidation of Criminal Code, 1960 (Act 29), Chapter 6 section 102 through 105 contains prohibitions against homosexuality. Ghana's official policy towards the gay male is homophobic and in consonance with the code. Considering the restrictions imposed on homosexuality by the Criminal Code, there appears to be the justification to bring homosexuals under the protective cover provided in Article 17 (1) through (3). Although male-to-male sex is illegal in Ghana, female-on-female sex is not and it is practiced by girls in boarding schools as a birth control mechanism to avoid having penile penetrative sex and thereby avoid pregnancy; adult lesbianism, like adult male homosexuality is also present in Ghana's society (Ankomah, 2001). The only difference is that while adult homosexuality is taken seriously with adverse consequences on the gay man, female homosexuality is not. It is often reasoned that a lesbian is still capable of sex with a male partner. But such liberal assessment of the potential of sex with a lesbian is not returned to the male homosexual who also has the innate capacity to father a child (Glassner et al.; 1979). Such a double standard in Ghana in terms of male and female homosexuality, may, perhaps, be explained by the value the national culture places on virility and procreation.

The psychosocial life of Ghana is male-centric and supported by the concept of male virility (Leiber, 2006; Norman et al., 2001; Carlson, McNutt, \& Choi, 2003; Norman, 2005; Ali, 2002; Kimmel, 1987; Buah, 1998). Women are deliberately kept in subordinate socio-political positions in terms of power dynamics in both domestic and professional lives (Pleck, Sonenstein \& Ku, 1993; Yamba, 2004; Bluwey, 1998; Ninsin, 2007; Vaughan, 1991). Since the end of colonial rule, the nation has undergone many socio-political and economic changes that are too numerous to enumerate. Despite the changes, the social norms of the nation regarding courtship, marriage, sexual behaviours, sexual freedoms and family, remains largely conventional in the urban centres and parochial in the rural areas (Archard, 1998; Norman, 2005). It is estimated that about two thirds of Ghana's current population live in the rural and peri-urban areas of the country. About $45 \%$ of the population is under 15 years of age, with $52 \%$ between 15 and 64 years of age, and about 3\% of the population is considered to be 65 years and older. The average life expectancy has improved considerably from 54 in 1995 to 57 years of age in 2010. Ankomah (2001) described the sexual culture of Ghana as a paradox. He proffered that, though many cultural artefacts such as Ghanaian traditional fables, tales and "high life" music, dances, jokes, and gibes were frequently woven around sex, the topic hardly came into the forefront for any formal discussion. Music, dance, jokes and gibes are not contradictory, neurotic or evanescent expressions. They are alternative media through which communication is established as a means of aggregation and abstraction of current socio-economic developments and its influences on the body politic (Bennett, 1999; Ashline, 2002; Smith, 2004; Anderson, 2009). Ankomah, therefore, took a limited view of what communication was or ought to be, and thus ran counter to the 
diversity of communication articulated by Bennet, Ashline and Anderson.

Many people in both developed and developing societies are reticent about discussing sexual matters in private, let alone, in public. Such reticence is not unique to Ghana but pervades the cultures of many nations and families, which is manifested even in private settings of family counsellors and psychologists (McFarland, Uecker, \& Regnerus, 2011; Boyd-Franklin, 1989, 1993; Davis \& Poctor, 1989; Falicov, 1983, 1998; McGoldrick et al., 1996; Minuchin et al., 1967; Okun, 1996; Pinderhughes, 1989). Religion also plays very significant roles in the lives of people. There are three main religions in Ghana, namely Christianity with (50\% of the population), Muslim has (14\%) and Traditional religion has (22\%) (Ghana Census Bureau, Statistical Service, 2010). Although other national experts have reported that Ghana is tolerant about religion and that there is no evidence of religious intolerance, in a recent study of violence and harassment in public universities and professional training institutions of Ghana, the study found the incidence of ethnic, racial and religious violence to be higher in comparison to sexual harassment (Norman et al., 2011).

Religion plays very influential role in moderating sexual desires and activities among the members of a particular group (McFarland, Uecker, \& Regnerus, 2011; Brothers, 1993; Burton, 1992; Butler \& Harper, 1994; Prest \& Keller, 1993). McFarland et al. (2011) reported that elevated religiosity, which they defined as church attendance and strength of religious identification, reduced the incidence of premarital sex among Catholics and conservative Protestants. However, the same was not true among liberal or moderate Protestants (Cochran, Chamlin, Beeghley, \& Fenwick, 2004). This suggests that religion may shape people's relationship to sexual activities such as masturbation, oral and anal sex, kissing and having multiple partners (McFarland, Uecker, \& Regnerus, 2011).

Despite the role of religion in limiting sexual experimentation of a given religious group, there appears to be other socio-demographic developments in the national sexual landscape that needs to be understood. These include the relationship between education and sexual freedom, marital union and quality of life, homosexuality and education and autoerotic behaviours (Carvalho \& Nobre, 2011; Nobre, 2006; Kerslake, 2004).

Homosexuality is a growing sexual behaviour which is trending among different societies; meanwhile there is a general homophobic attitude towards them in most African countries including Ghana. Also, because of the general belief systems across a country like Ghana, homosexuality is generally not tolerated.

This study is evidence based, which highlights the fact that though homosexuality is a crime in Ghana, it is indeed being practiced among some members of the population. There is general agitation and focused activism against homosexuality on one hand and acceptance on the other hand. It is therefore imperative to encourage open and honest discussion of sex, sexuality and sexual activities in order to identify the gaps in the socio-cultural framework as well as in the legislative framework and address them.

\section{Methods}

This is a cross-sectional study. It consisted of questionnaire survey, desktop and internet review. The study targeted the general population of Ghana but looked at only people who were at least 16 years old. The study was purely exploratory and did not test any hypothesis. Performing a house-to-house survey was not the best in this case since it was quite impossible obtaining a sampling frame regarding housing distributions at that time. Also due to the sensitive nature of the study, it was better to interview them out of their (respondents) homes. Sampling selection was thus of random nature, pre-stratified by gender and region according to projections from the Ghana Statistical Service for that year (2009).

We recruited three research assistants and over a period of one week provided them with about 20 hours of lecture, discussion, and case studies of previous research on sex, sexuality, incest, homosexuality and lesbianism, cultural and religious views on sex, procreation and male dominance over females. We also identified and discussed the prevailing cultural and national attitudes towards gender roles and the family. The study formed part of a large study on sexual harassment and violence as well as ethnic and religious harassment and violence within institutions of Ghana. The nation was divided among the three research assistants by region. Between June and July of 2009, they travelled to their respective locations to administer the questionnaires based on the pre-determined sample sizes for each region by a simple random method. At each stratum, respondents were invited anonymously to fill out the questionnaire after which they handed it over to the research assistant. The research assistant was available to provide help if need be.

After the collection, data entry was done using the Statistical Package for Social Sciences (SPSS). Descriptive 
and exploratory analyses were carried out using SPSS to assess if there are trends in the sexual mores of a conventional society (Ghana); and to assess if there is association between psychosocial background and sexual attitudes. Analyses were also carried out to find the demographic characteristics of respondents as well as their sexual attitudes and behaviors. Further analyses using SPSS and STATA (Chi-square tests and logistic regression methods) were also carried out to explore if there were associations between respondents' background, sexual behaviours and orientation.

Internet search was also conducted using carefully designed keywords such as "homosexuality, Ghana", "trends, sexuality modern Ghana”, or "Ghana, heterosexuality, lesbianism, bisexuality", "Developments in marital union", "Pornography, prostitution, Ghana”. The result was overwhelming, running into millions of data on sexuality in general, but on Ghana specific sexuality issues, there were over 70,000 results obtained most of which did not only concern Ghana. Despite the large volume of literature on sexuality on the internet, there were a few studies that alluded to trends in the sexual mores of Ghana such as that of Ankomah (1992), but did not provide a more comprehensive investigative outcome. The results from the search that were deemed pertinent to the study were analyzed and incorporated into the literature review. Additionally, the legislative framework on sexual offences was compared with international best practices.

\section{Results}

The response rate to the questionnaire developed for this purpose was 974/1068 (91.2\%). This may be attributable to those who decline to associate with a particular age group or perhaps did not know their correct ages. There were 484 females and the rest were males. Of the females, 307/484 (63.4\%) were between ages 21 and 30 . Among the male respondents of 490, 278/490 (57\%) were also between ages 21 and 30. For the females 90/484 (19\%) ranged in age from 31 to 46 and over, whiles the men at the same range were 154/490 (31.4\%).

Of the females, 320/464 (69\%) were single whiles among the men, the singles were 328/477 (69\%) as well. Those married were 114/464 (25\%) for females and 112/477 (24\%) for males. Divorced were 30/464 (7\%) and $37 / 477$ (8\%) for females and males respectively as demonstrated in Table 1

\subsection{Commencement of Sexual Activities}

Between ages 10 and 14, 13\% of both the females and males have lost their virginity. This number increases dramatically between ages 15 and 20 where $58 \%$ of the females and $49 \%$ of the males reported having had sex at least once already as shown in Figure 1. The timing of sexual intercourse in this study is consistent with findings from other places among the youth and adolescence (Crockett, Bingham, Chopak, \& Vicary, 1996).

\subsubsection{Experience with Anal Sex or Homosexuality and Sexual Experimentation}

About 27\% of the respondents have had either anal sex or have had homosexual experience before as shown in Figure 2 and Figure 3.

The curiosity of Ghanaians in sex appears to be quite extensive. They seem ready to try multiple configurations of sexual activities, including having sex with multiple partners (ménage-a-trois) at the same time. More than $24 \%$ of the males and $19 \%$ of the females said they would like to try to have sex with three, four or five persons at the same time as shown in Figure 4.

\subsubsection{Getting Turned on}

According to Table 2, while the females consider genitals of their partner as a more arousing agent in them, followed by the lips, the males consider their partner's breast as the instigator of sexual desires in them, followed by the lips.

These were also characteristic of respondent who had been exposed to, or practiced homosexuality.

\subsection{Analysis of Sexual Trends Captured in Table 3}

In Table 3, the cross tabulation of the background of the respondents and their sexual orientation showed that a number of Ghanaians have had bi-sexual experiences before, irrespective of religious affiliations. Looking at religious orientation and sexuality, it was revealed that 184/442 (42\%) of Christians and 45/108 (42\%) of 
Table 1. Background characteristics of respondents.

\begin{tabular}{|c|c|c|c|c|}
\hline \multicolumn{2}{|c|}{ Background characteristics } & \multirow{2}{*}{$\begin{array}{c}\text { Female n (\%) } \\
87(18.0)\end{array}$} & \multirow{2}{*}{$\begin{array}{c}\text { Male n (\%) } \\
58(11.8)\end{array}$} & \multirow{2}{*}{$\begin{array}{c}\text { Total n (\%) } \\
145 \text { (14.9) }\end{array}$} \\
\hline \multirow{7}{*}{ Age } & $16-20$ & & & \\
\hline & $21-25$ & $191(39.5)$ & 149 (30.4) & 340 (34.9) \\
\hline & $26-30$ & $116(24.0)$ & $129(26.3)$ & $245(25.2)$ \\
\hline & $31-35$ & $35(7.2)$ & 71 (14.5) & $106(10.9)$ \\
\hline & $36-40$ & $31(6.4)$ & $34(6.9)$ & $65(6.7)$ \\
\hline & $41-45$ & $11(2.3)$ & $22(4.5)$ & $33(3.4)$ \\
\hline & 46 and over & $13(2.7)$ & $27(5.5)$ & $40(4.1)$ \\
\hline \multirow{5}{*}{ Marital Status } & Total & $484(100.0)$ & $490(100.0)$ & $974(100.0)$ \\
\hline & Single & $320(69.0)$ & $328(68.8)$ & 648 (68.9) \\
\hline & Married & $114(24.6)$ & $112(23.5)$ & $226(24.0)$ \\
\hline & Divorced & $30(6.5)$ & $37(7.8)$ & $67(7.1)$ \\
\hline & Total & $464(100.0)$ & $477(100.0)$ & $941(100.0)$ \\
\hline \multirow{4}{*}{ Parental Status ${ }^{*}$} & Single parent & $102(20.8)$ & $34(6.7)$ & $136(13.7)$ \\
\hline & Married with children & 96 (19.6) & $104(20.6)$ & $200(20.1)$ \\
\hline & Married without children & $39(8.0)$ & $59(11.7)$ & $98(9.8)$ \\
\hline & Not applicable & $253(51.6)$ & $308(61.0)$ & $561(56.4)$ \\
\hline \multirow{6}{*}{$\begin{array}{l}\text { Religious } \\
\text { Orientation }\end{array}$} & Total & $490(100.0)$ & $505(100.0)$ & $995(100.0)$ \\
\hline & Atheist & $35(8.0)$ & $54(11.4)$ & $89(9.8)$ \\
\hline & Christian & 337 (77.1) & 328 (69.1) & 665 (72.9) \\
\hline & Moslem & $57(13.0)$ & $75(15.8)$ & $132(14.5)$ \\
\hline & Animist & $8(1.8)$ & $18(3.8)$ & $26(2.9)$ \\
\hline & Total & $437(100.0)$ & $475(100.0)$ & $912(100.0)$ \\
\hline \multirow{5}{*}{$\begin{array}{c}\text { Educational level } \\
\text { completed }\end{array}$} & JSS & $39(9.8)$ & $30(7.2)$ & $69(8.5)$ \\
\hline & SSS & $208(52.1)$ & 209 (50.5) & 417 (51.3) \\
\hline & Vocational & $61(15.3)$ & $20(4.8)$ & $81(10.0)$ \\
\hline & Technical & 40 (10.0) & $101(24.4)$ & 141 (17.3) \\
\hline & University & $51(12.8)$ & $54(13.0)$ & 105 (12.9) \\
\hline \multirow{7}{*}{ Race } & Total & $399(100.0)$ & $414(100.0)$ & $813(100.0)$ \\
\hline & Black & $376(81.4)$ & 389 (82.1) & $765(81.7)$ \\
\hline & White & $24(5.2)$ & $6(1.3)$ & $30(3.2)$ \\
\hline & Asian & $21(4.5)$ & $34(7.2)$ & 55 (5.9) \\
\hline & Arab & $20(4.3)$ & $26(5.4)$ & $46(4.8)$ \\
\hline & Mixed Race & $21(4.5)$ & $19(4.0)$ & $40(4.3)$ \\
\hline & Total & $462(100.0)$ & $474(100.0)$ & $936(100.0)$ \\
\hline
\end{tabular}

"The large number "Not Applicable", 561 (56.4\%) may be attributed to those who were either without children or declined to answer.

Table 2. Getting Turned on.

\begin{tabular}{|c|c|c|c|c|c|}
\hline & Getting turned on & Female n (\%) & Male n (\%) & Total n (\%) & $p$-value \\
\hline \multirow{11}{*}{$\begin{array}{l}\text { I get turned on } \\
\text { by my lover's }\end{array}$} & Foot & $14(4.6)$ & $24(8.5)$ & 38 (6.5) & \multirow{10}{*}{0.000} \\
\hline & Arms & $8(2.6)$ & $16(5.7)$ & $24(4.1)$ & \\
\hline & Legs & $13(4.2)$ & $10(3.6)$ & $23(3.9)$ & \\
\hline & Breast & $26(8.5)$ & 89 (31.7) & 115 (19.6) & \\
\hline & Lips & 34 (11.1) & $23(8.2)$ & 57 (9.7) & \\
\hline & Eyes & $26(8.5)$ & $26(9.3)$ & $52(8.8)$ & \\
\hline & Genitals & $92(30.0)$ & $31(11.0)$ & $123(20.9)$ & \\
\hline & Shoes & $8(2.6)$ & $9(3.2)$ & $17(2.9)$ & \\
\hline & Silk clothes & $8(2.6)$ & $8(2.8)$ & $16(2.7)$ & \\
\hline & None of the above & $78(25.4)$ & $45(16.0)$ & 123 (20.9) & \\
\hline & Total & $307(100.0)$ & $281(100.0)$ & $588(100.0)$ & \\
\hline
\end{tabular}




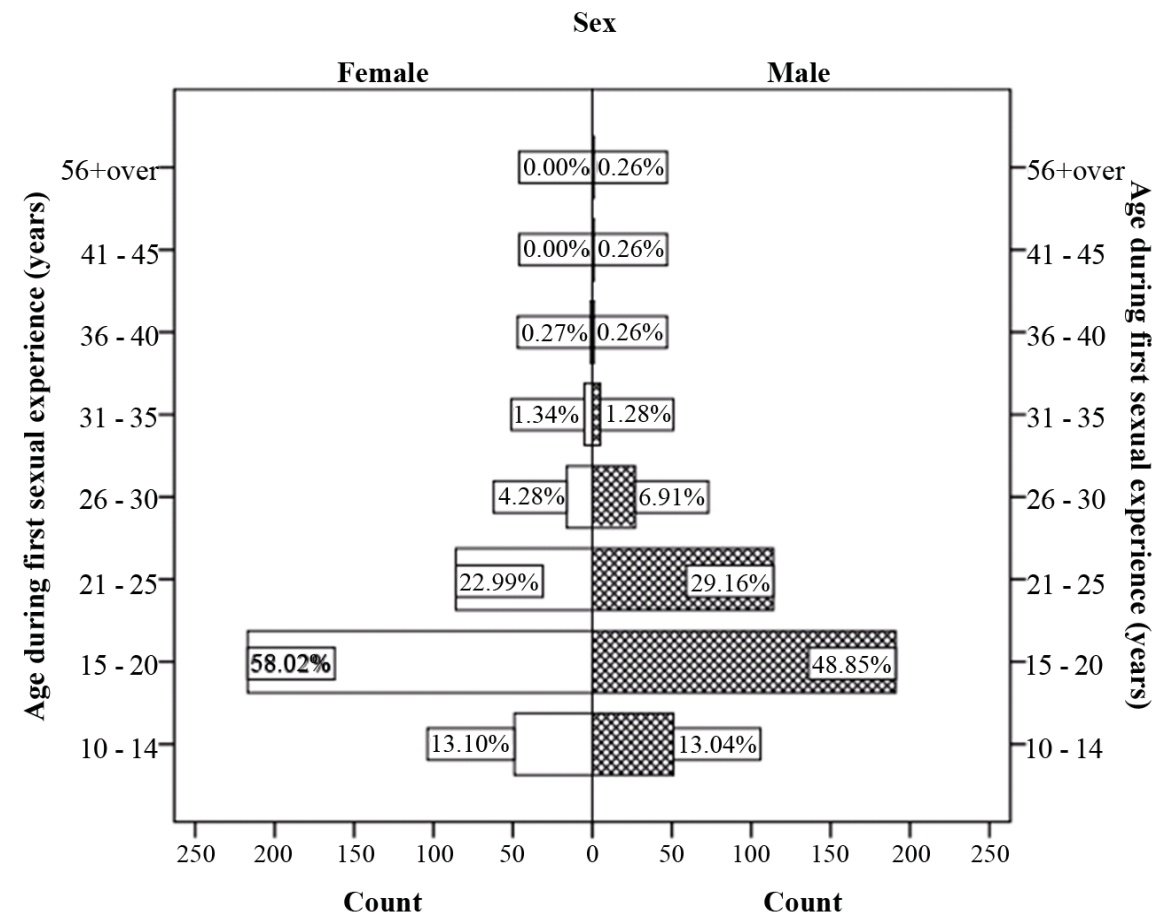

Figure 1. The figure shows the commencement of sexual activities between males and females (showing percentages within the individual sexes).

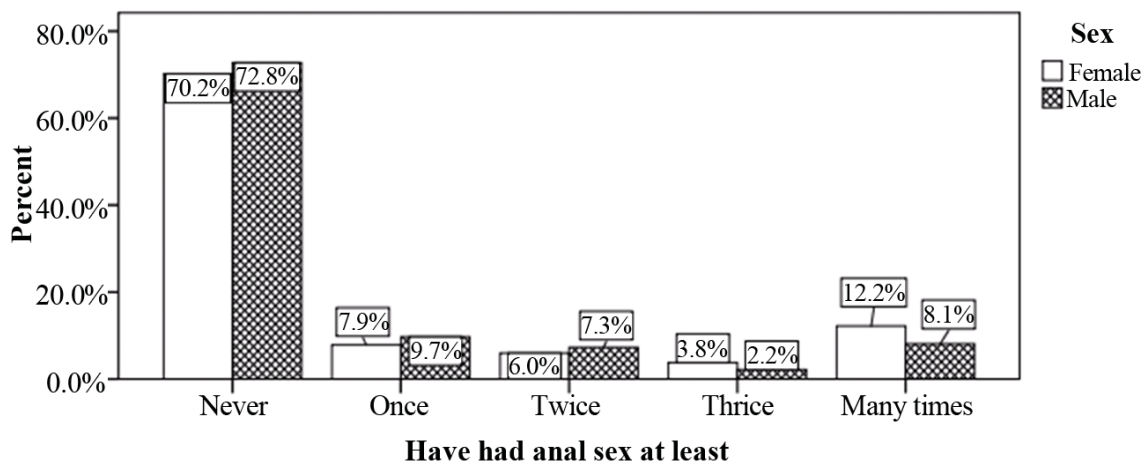

Figure 2. The figure shows the experience of respondents with anal sex.

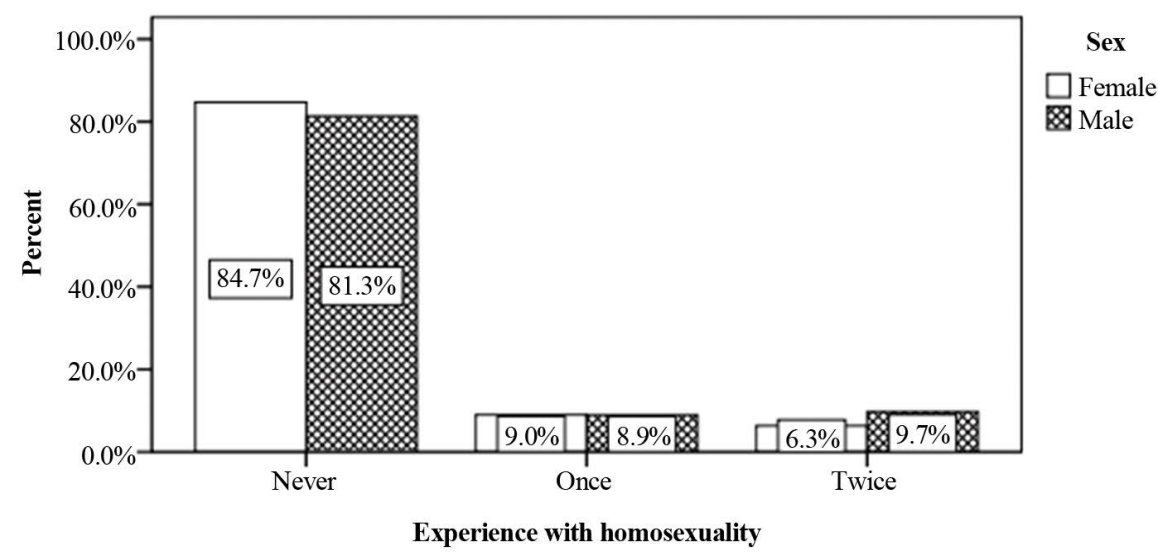

Figure 3. The figure shows experience with homosexuality among respondents. 


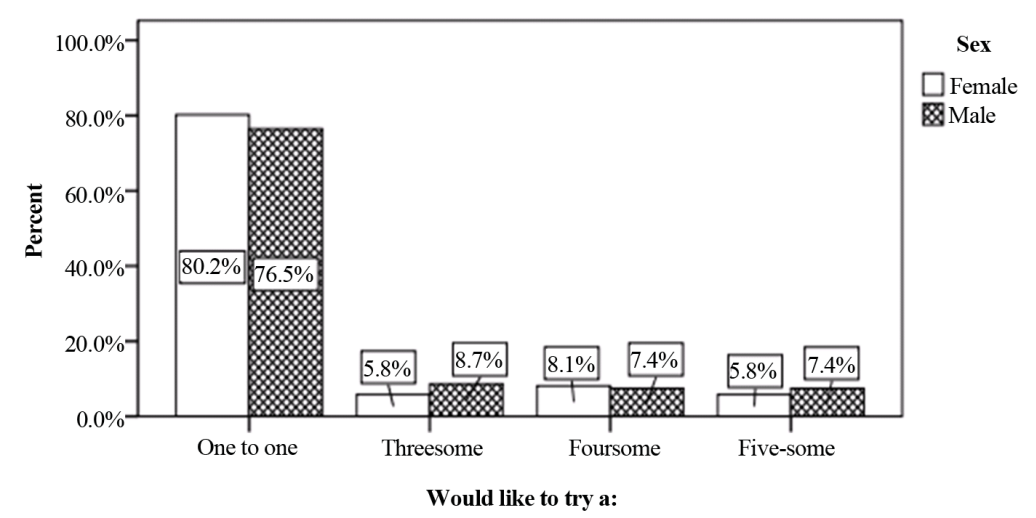

Figure 4. The figure shows experimentation with multiple partners.

Table 3. Multiple-crosstabs between background of respondents and sexual orientation (showing Pearson chi-square/ Fisher's exact test p-values).

\begin{tabular}{|c|c|c|c|c|c|}
\hline \multirow[b]{2}{*}{ Background Variables } & \multicolumn{4}{|c|}{ Sexual Orientation [n (\%)] } & \multirow[b]{2}{*}{$p$-value } \\
\hline & Homosexual & Heterosexual & Bi-sexual & Total & \\
\hline \multicolumn{6}{|l|}{ Age (years) } \\
\hline $16-20$ & $8(9.4)$ & $32(37.6)$ & 45 (52.9) & $85(100.0)$ & \multirow{7}{*}{0.000} \\
\hline $21-25$ & $8(3.7)$ & $123(57.5)$ & $83(38.8)$ & $214(100.0)$ & \\
\hline $26-30$ & $8(4.2)$ & $91(47.4)$ & $93(48.4)$ & $192(100.0)$ & \\
\hline $31-35$ & $3(3.3)$ & $63(68.5)$ & $26(28.3)$ & $92(100.0)$ & \\
\hline $36-40$ & $2(3.2)$ & $40(64.5)$ & $20(32.3)$ & $62(100.0)$ & \\
\hline $41-45$ & $2(6.7)$ & $23(76.7)$ & $5(16.7)$ & $30(100.0)$ & \\
\hline 46 and over & $7(18.4)$ & $18(47.4)$ & $13(34.2)$ & $38(100.0)$ & \\
\hline \multicolumn{6}{|l|}{ Sex } \\
\hline Female & $19(5.5)$ & $191(55.5)$ & $134(39.0)$ & $344(100.0)$ & \multirow{2}{*}{0.747} \\
\hline Male & $18(5.0)$ & $190(53.2)$ & $149(41.7)$ & $357(100.0)$ & \\
\hline \multicolumn{6}{|l|}{ Marital Status } \\
\hline Single & $20(4.8)$ & $216(52.0)$ & 179 (43.1) & 415 (100.0) & \multirow{3}{*}{0.000} \\
\hline Married & $6(2.9)$ & 131 (63.9) & 68 (33.2) & $205(100.0)$ & \\
\hline Divorced & $10(15.9)$ & $24(38.1)$ & $29(46.0)$ & $63(100.0)$ & \\
\hline \multicolumn{6}{|l|}{ Parents } \\
\hline Single parent & $10(8.1)$ & 47 (37.9) & $67(54.0)$ & $124(100.0)$ & \multirow{3}{*}{0.090} \\
\hline Married with children & $9(4.9)$ & $98(53.3)$ & 77 (41.8) & $184(100.0)$ & \\
\hline Married without children & $7(7.8)$ & $38(42.2)$ & $45(50.0)$ & $90(100.0)$ & \\
\hline \multicolumn{6}{|l|}{ Religious Orientation } \\
\hline Non-believer & $10(12.7)$ & 32 (40.5) & 37 (46.8) & $79(100.0)$ & \multirow{4}{*}{0.002} \\
\hline Christian & $15(3.4)$ & $243(55.0)$ & $184(41.6)$ & $442(100.0)$ & \\
\hline Moslem & $8(7.4)$ & 55 (50.9) & 45 (41.7) & $108(100.0)$ & \\
\hline Animist & $3(12.5)$ & $7(29.2)$ & $14(58.3)$ & $24(100.0)$ & \\
\hline \multicolumn{6}{|l|}{ Educ. level completed } \\
\hline JSS & 8 (14.5) & 17 (30.9) & $30(54.5)$ & $55(100.0)$ & \multirow{5}{*}{0.001} \\
\hline SSS & $10(3.9)$ & $139(54.1)$ & $108(42.0)$ & $257(100.0)$ & \\
\hline Vocational & $4(5.0)$ & $48(60.0)$ & $28(35.0)$ & $80(100.0)$ & \\
\hline Technical & $9(7.2)$ & 71 (56.8) & $45(36.0)$ & $125(100.0)$ & \\
\hline University & $2(2.6)$ & $34(43.6)$ & $42(53.8)$ & $78(100.0)$ & \\
\hline \multicolumn{6}{|l|}{ Race } \\
\hline Black & $25(4.7)$ & 306 (57.3) & $203(38.0)$ & 534 (100.0) & \multirow{7}{*}{0.000} \\
\hline White & $1(3.3)$ & $6(20.0)$ & $23(76.7)$ & $30(100.0)$ & \\
\hline Asian & $3(10.3)$ & $11(37.9)$ & 15 (51.7) & $29(100.0)$ & \\
\hline Lebanese & $1(2.6)$ & $16(42.1)$ & $21(55.3)$ & $38(100.0)$ & \\
\hline Syrian & $0(0.0)$ & $0(0.0)$ & $3(100.0)$ & $3(100.0)$ & \\
\hline Persian & $3(50.0)$ & 1 (16.7) & $2(33.3)$ & $6(100.0)$ & \\
\hline Mixed Race & $3(7.9)$ & $22(57.9)$ & $13(34.2)$ & $38(100.0)$ & \\
\hline
\end{tabular}

*We have classified the dominant Arab populations in Ghana into their respective nationalities to provide a clearer picture and to show their distinct identities. 
Table 4. Summary of logistic regression odds ratios (sexual orientation (dependent) based on socio-demographic factors (predictors) which were run separately).

\begin{tabular}{|c|c|c|c|}
\hline \multirow[b]{3}{*}{ Independent Variables } & \multicolumn{3}{|c|}{ Odds Ratios (95\% C.I. for Odds Ratios) } \\
\hline & \multicolumn{3}{|c|}{ Dependent Variables } \\
\hline & Homosexual & Heterosexual & Bisexual \\
\hline $\begin{array}{l}\text { Age (years) } \\
{ }^{1} 16-20\end{array}$ & 3,4 & 3,4 & 3,4 \\
\hline $21-25$ & $0.374(0.136,1.031)$ & $2.239(1.337,3.749)^{2}$ & $0.563(0.339,0.935)^{2}$ \\
\hline $26-30$ & $0.418(0.152,1.155)$ & $1.492(0.885,2.516)$ & $0.835(0.501,1.392)$ \\
\hline $31-35$ & $0.324(0.083,1.266)$ & $3.598(1.933,6.697)^{2}$ & $0.350(0.188,0.652)^{2}$ \\
\hline $36-40$ & $0.321(0.066,1.567)$ & $3.011(1.525,5.947)^{2}$ & $0.423(0.214,0.837)^{2}$ \\
\hline $41-45$ & $0.688(0.138,3.435)$ & $5.442(2.098,14.114)^{2}$ & $0.178(0.062,0.508)^{2}$ \\
\hline 46 and over & $2.173(0.726,6.508)$ & $1.491(0.688,3.230)$ & $0.462(0.209,1.023)$ \\
\hline \multicolumn{4}{|l|}{$\begin{array}{c}\text { Sex } \\
{ }^{1} \text { Female }\end{array}$} \\
\hline Male & $0.908(0.468,1.761)$ & $0.911(0.677,1.227)$ & $1.123(0.830,1.518)$ \\
\hline $\begin{array}{l}\text { Marital Status } \\
{ }^{1} \text { Single }\end{array}$ & 3,4 & 3,4 & 3,4 \\
\hline Married & $0.595(0.235,1.506)$ & $1.631(1.156,2.301)^{2}$ & $0.654(0.461,0.928)^{2}$ \\
\hline Divorced & $3.726(1.655,8.389)^{2}$ & $0.567(0.329,0.977)^{2}$ & $1.125(0.660,1.915)$ \\
\hline $\begin{array}{l}\text { Parental Status } \\
{ }^{1} \text { Single parent }\end{array}$ & 3 & 3,4 & 3,4 \\
\hline Married with children & $0.586(0.231,1.487)$ & $1.867(1.174,2.970)^{2}$ & $0.612(0.387,0.969)^{2}$ \\
\hline Married without children & $0.961(0.351,2.630)$ & $1.197(0.688,2.083)$ & $0.851(0.494,1.465)$ \\
\hline & ${ }^{1}$ Non-believer & 3,4 & 3 \\
\hline Christian & $0.242(0.105,0.561)^{2}$ & $1.793(1.102,2.918)^{2}$ & $0.810(0.501,1.309)$ \\
\hline Moslem & $0.552(0.207,1.469)$ & $1.524(0.848,2.740)$ & $0.811(0.452,1.455)$ \\
\hline Animist & $0.986(0.248,3.916)$ & $0.605(0.225,1.625)$ & $1.589((0.631,4.004)$ \\
\hline $\begin{array}{c}\text { Educ. Level Completed } \\
{ }^{1} \mathrm{JSS}\end{array}$ & 3,4 & 3,4 & 3,4 \\
\hline SSS & $0.238(0.089,0.634)^{2}$ & $2.633(1.413,4.906)^{2}$ & $0.604(0.336,1.085)$ \\
\hline Vocational & $0.309(0.088,1.084)$ & $3.353(1.622,6.930)^{2}$ & $0.449(0.222,0.905)^{2}$ \\
\hline Technical & $0.456(0.166,1.253)$ & $2.939(1.500,5.758)^{2}$ & $0.469(0.246,0.893)^{2}$ \\
\hline University & $0.155(0.031,0.759)^{2}$ & $1.727(0.836,3.571)$ & $0.972(0.486,1.944)$ \\
\hline $\begin{array}{l}\text { Educational Status } \\
{ }^{1} \text { Never been to school }\end{array}$ & & 4 & 4 \\
\hline Dropped out of JSS & $0.566(0.056,5.686)$ & $1.556(0.167,14.455)$ & $0.975(0.164,5.787)$ \\
\hline Still in school & $0.380(0.043,3.379)$ & 4.365 (0.505, 37.743) & $0.432(0.078,2.387)$ \\
\hline Race & 3,4 & 3,4 & 3,4 \\
\hline \multicolumn{4}{|l|}{${ }^{1}$ Black } \\
\hline White & $0.702(0.092,5.364)$ & $0.186(0.075,0.463)^{2}$ & $5.357(2.258,12.710)^{2}$ \\
\hline Asian & $2.349(0.666,8.288)$ & $0.455(0.211,0.983)^{2}$ & $1.747(0.826,3.695)$ \\
\hline Lebanese & $0.550(0.073,4.175)$ & $0.542(0.278,1.055)$ & $2.014(1.038,3.908)^{2}$ \\
\hline Syrian & 0.000 (None) & 0.000 (None) & 2.634E9 (None) \\
\hline Persian & $20.360(3.911,106.004)^{2}$ & $0.149(0.017,1.284)$ & $0.815(0.148,4.491)$ \\
\hline Mixed Race & $1.745(0.502,6.064)$ & $1.025(0.526,1.995)$ & $0.848(0.424,1.695)$ \\
\hline
\end{tabular}

${ }^{1}$ Logistic regression reference variable; ${ }^{2}$ Significant variable(s) within model; Model satisfies Hosmer-Leme show goodness-of-fit test; ${ }^{4}$ Overall model significant to each variable in each segment.

Moslems reported being bi-sexual. Among those aged between 16 and 20, 53\% of them had had bi-sexual encounter before, while only 39\% of those aged between 21 and 25, and 48\% of those aged between 26 - 30 reported being bi-sexual. Despite their small number, 7/38 (18\%) of those aged 46 and above said they were homosexuals, with another 13/38 (34\%) reporting bi-sexuality among both sexes. A separate look at gender revealed that, 134/344 (39\%) of the females were bi-sexual, while the males were even greater, recording 149/357 (42\%) as bi-sexual. Marital status was not a bar to bi-sexuality. Among the married, 68/205 (33\%) reported be- 
ing bi-sexual with another 6/205 (3\%) being homosexual. This could simply mean that even though the individual is married, he or she considers himself or herself as a homosexual. Homosexuality amongst the divorce was 10/63 (16\%) and bi-sexuality in their group was 29/63 (46\%).

\section{Summary of Logistic Regression}

From the logistic regression equations, the study found that those above 20 years and older were less likely to be bisexual; compared to those between 16 and 20 years of age. In the case of homosexuality, those above 46 were more likely to be gay compared to those below 46 years of age. In the case of divorcees, they seemed to be three times more likely to be homosexuals than those married or single but less likely to be heterosexual. Please see Table 4 below for other comparisons.

Interpretation: e.g. Compared to Blacks (indigenous Ghanaians), Whites were 0.186 times more likely to be heterosexual (or $1 / 0.186=5.376$ times less likely because 0.186 is less than (1). The model to test heterosexuality among the different races is significant $(3,4)$ although not all the categories are $(2)$.

\section{Discussion}

The sexual health of a transitional society like Ghana presents a complex matrix for analysis due to the sheer size and the belief systems of the social groups involved. Culturally, each group may have a different set of goals for its self-determination within the collective (Archard, 1998). Additionally, their quality of life issues are undercut by religion, socio-cultural norms and limitations as well as demographic differences. We began this investigation by looking at what sexual health may mean to the people of Ghana. In Ghana there is no clear articulation of what sexual health means and so we borrowed from the World Health Organization (WHO). In 2006, WHO defined sexual health as:

“... a state of physical, emotional, mental, and social well-being in relation to sexuality; it is not merely the absence of disease, dysfunction or infirmity. Sexual health requires a positive and respectful approach to sexuality and sexual relationships, as well as the possibility of having pleasurable and safe sexual experiences, free of coercion, discrimination and violence. For sexual health to be attained and maintained, the sexual rights of all persons must be respected, protected and fulfilled.” (WHO, 2006).

This provides the basis for the protection of both heterosexual and homosexual relationships. Embedded in the WHO definition are medical and mental health issues, aside of the ethical and legal protections that the definition and national laws impose on member states to honour. For example, the 1992 Constitution of Ghana, Article 14 (1) guarantees personal liberties of all persons. Article 17 (2) and (3) go further to protect citizens that may be "discriminated against on the grounds of gender, race, colour, ethnic origin, religion, creed or social or economic status". The constitutional protection appears to cover both the economic underclass, i.e. the poor and aged, but social underclass as well, i. e. homosexuals and lesbians. Sexual groups constitute social classes. This position is further strengthened by Article 17 (3) of the 1992 Constitution which states:

... "discriminate" means to give different treatment to different persons attributable only or mainly to their respective descriptions by race, place of origin, political opinions, colour, gender, occupation, religion or creed, whereby persons of one description are subjected to disabilities or restrictions to which persons of another description are not made subject or are granted privileges or advantages which are not granted to persons of another description."

A liberal reading of this suggests that different sexual groups such as homosexuals and lesbians should be accorded the same status as heterosexual groups since they fall into the "persons of another description" and are not to be subjected to disabilities or restrictions to which persons of another description are not made subject to...” Each sexual group has compelling and different sexual and medical health issues (Horowitz et al., 2001; Kuyper \& Vanwesenbeeck 2003; Smith et al., 1987).

In this study, we have demonstrated that homosexuality is part of the sexual mores of Ghanaian society despite its level of material and industrial progress and it included respondents among various classes and age groups (Table 1). The declaration of sexual autonomy and independence would become more common as the Ghanaian society as well as those in Sub-Sahara Africa move from agrarian and parochial communities and settlements into the more urbanized, semi-industrialized and commercial entity within the globalized world. Sex, sexuality and their related activities have also morphed into a more modern form, which renders traditional 
views on sex, sexuality and activities antiquated; and the age of commencement of sexual activities also varies (Figure 1) in the Ghanaian society.

It appears Ghana seems to be evaluating its thinking about the potential cost to culture if it allowed a complete overhaul of the antediluvian views of sex and sexuality of society, as it entrenches its status as middle income, urbanized society. Whiles long ways away from being accepted, male homosexuality is gradually but slowly being considered and discussed in mainstream media by Ghanaians. Perhaps, it should be allowed to remain as anomalous to the nature of heterosexuality but not to nature itself. On some level, there is an unflinching desire on the part of the population to maintain 'the embodiments of hegemonic masculinity, or its imitations' and to permit homosexuality and lesbianism to co-exist and to operate alongside heterogeneity how be it, secretively (Ozbay, 2010: p. 659; Friedman, 2001; Prest \& Keller, 1993). This is perhaps why in Ghana, lesbianism (or in local language, "Supi" or otherwise something more superior to the norm) is not as frowned upon as much as male homosexuality. To do otherwise, is to deny the statistics: where 179/415 (43\%) of single individuals describe themselves as bi-sexual, ( $p$-value $=0.000)$, and 77/184 $(42 \%)$ of those married with children describe themselves as bi-sexual and with $(5 \%)$ admitting that they are homosexual, $(p$-value $=0.090)$ (Table 3), with Table 4 comparing other demographic and social factors which increases likelihoods of homosexuality, bisexuality or heterosexuality. It appears but for the fear of being lynched or even killed, those describing themselves as bi-sexual would have probably identified more with straight out homosexuality. Whether bi-sexuality or homosexuality, more and more Ghanaians seem to be engaging in anal sex, or have had an experience with homosexuality (Figure 3) and are willing to report it, although anonymously. This is a good sign that the society is no longer as reticent about discussing sexual proclivities as initially considered. Although $73 \%$ of males said they had never had anal sex, the rest of them have had anal sex at least once; more females have had anal sex than males, like their male counterparts, $70.2 \%$ of females said they had never had anal sex (Figure 2). Figure 4 also proves that there is experimentation with multiple partners proving the fact that some respondents in the Ghanaian population are becoming more and more exploratory when it comes to sex as shown in Table 2. These phenomena have tremendous effect on public health policy and programs.

\subsection{Study Limitations}

In looking at the sexual habits of people, it is difficult to audit the true nature of the information provided by respondents. As far as Ghana is concerned, this is the first of its kind where a cross-sectional study of this nature has been carried out. Our study surveyed all the regions in the nation, though not a longitudinal study, it offers the best option to understanding the trends in sexuality in Ghana thus far. Admittedly, the sample could be biased. The return rate was a hundred percent although not all the questions were answered by all the respondents. This could be attributable to the youthfulness of the research assistants, who established a rapport with the respondents. The respondents could have been waiting for an opportunity to share their knowledge about their sexual behaviours and thus were probably happy to participate in this study. Due to the self-reporting nature of the questionnaire administered, it is possible that respondents might not be truthful, or have difficulty in expressing the true nature of their sexual proclivities and thus leading to poor characterization. There is no other alternative method for such surveys, however. Therefore, despite the limitations, we believe the study still contributes to knowledge on sexual trends and groups in Ghana and the in Sub-Sahara Africa and the world. Each sexual group has compelling and different sexual and medical health issues, which needs the attention of all.

\subsection{Conclusion}

Communication about sexuality between patients and doctors is strained or self-censored in the face of HIV and AIDs and associated high risk behaviours such as men-on-men sex and other practices such as anal sex between men and women. The trends identified by this study within the Ghanaian sexual mores are interesting and immense. The public health implications are unimaginable. It is therefore imperative to encourage open and honest discussion of sex, sexuality and sexual activities in order to identify the gaps in the socio-cultural framework as well as in the legislative framework and address them.

\section{Acknowledgements}

We are grateful to Dr. Akwasi Osei, CEO, Ghana Mental Health Authority for his insightful contribution to improve the quality of this paper. 


\section{References}

Adams, J., McCreanor, T., \& Braun, V. (2008). Doctoring New Zealand’s Gay Men. New Zealand Medical Journal, 121, $11-20$.

Ali, K. (2002). Special Focus: Islam, Same-Sex Sexual Activity and Lesbian and Bisexual Women. http://www.brandeis.edu/projects/fse/Pages/femalehomosexuality.html

Alston, J. P. (1974). Attitudes towards Extramarital and Homosexual Relations. Journal for the Scientific Study of Religion, 13, 479-481. http://dx.doi.org/10.2307/1384611

Anderson, T. L. (2009). Better to Complicate, Rather than Homogenize, Urban Nightlife: A Response to Grazian. Sociological Forum, 24, 918-925. http://dx.doi.org/10.1111/j.1573-7861.2009.01144.x

Ankomah, A. (2001). The International Encyclopedia of Sexuality: Ghana. In R. T. Francoeur (Ed.), New York: Continuum.

Appiah, A. K. (2006). Citizen of the World.

http://www.princeton.edu/paw/archive new/PAW05-06/11-0405/features kwame.html

Archard, D. (1998). Limits of Consensuality, Sexual Consent. Boulder, CO: West View Press, 39-89.

Ashline, W. (2002). Clicky Aesthetics: Deleuze, Headphones and the Minimalist Assemblage of “Aberrations”. Journal of Theory, Culture and Politics, 15, 87-101. http://dx.doi.org/10.1080/10402130220127861

Bennett, A. (1999). Subculture or Neo-Tribes? Rethinking the Relationship between Youth, Style and Musical Taste. Journal of Sociology, 33, 599-617.

Bhugra, D. (2010). Homophobia: A Review of the Literature. Sexual and Relationship Therapy, 25, 456-464. http://dx.doi.org/10.1080/14681994.2010.518723

Biaya, T. K. (1999). Eroticism and Sexuality in Africa: Directions and Illusions. CODESRIA Bulletin, 1999, 41-46.

Black, K., \& Stevenson, M. (1984). The Relationship of Self-Reported Sex-Role Characteristics and Attitudes towards Homosexuality. In J. P. De Cecco (Ed.), Homophobia: An Overview (pp. 83-94). New York: Haworth Press.

Bleek, W. (1976). Sexual Relationships and Birth Control in Ghana: A Case Study of a Rural Town. Amsterdam: Centre for Social Anthropology, University of Amsterdam.

Bluwey, G. K. (1998). State Organizations in the Transition to Constitutional Democracy. In K. A. Ninsin (Ed.), Ghana: Transition to Democracy (pp. 105-111). Accra: Freedom Publications.

Bowman, R. (1979). Public Attitudes towards Homosexuality in New Zealand. International Review of Medical Sociology, 9 , 229-238.

Boyd-Franklin, N. (1989). Black Families in Therapy: A Multi-Systems Approach. New York: Guilford Press.

Boyd-Franklin, N. (1993). Race, Class, and Poverty. In F. Walsh (Ed.), Normal Family Processes (2nd ed., pp. 361-376). New York: Guilford Press.

Brothers, B. J. (Ed.) (1993). Spirituality and Couples: Heart and Soul in the Therapy Process. New York: Haworth Press.

Buah, F. K. (1998). A Short History of Ghana. Oxford: Macmillan Education, 43 p.

Burton, L. A. (Ed.) (1992). Religion and the Family. New York: Haworth Press.

Butler, M. A., \& Harper, J. M. (1994). The Divine Triangle: God in the Marital System of Religious Couples. Family Process, 33, 277-286. http://dx.doi.org/10.1111/j.1545-5300.1994.00277.x

Cameron, P., \& Ross, K. (1981). Social-Psychological Aspects of the Judeo-Christian Stance towards Homosexuality. Journal of Psychology and Theology, 9, 40-57.

Carlson, B. E., McNutt, L. A., \& Choi, D. Y. (2003). Childhood and Adult Abuse among Women in Primary Health Care: Effects on Mental Health. Journal of Interpersonal Violence, 18, 924-941. http://dx.doi.org/10.1177/0886260503253882

Carvalho, J., \& Nobre, P. (2011). Predictors of Men’s Sexual Desire: The Role of Psychological, Cognitive-Emotional, Relational, and Medical Factors. Journal of Sex Research, 48, 254-262. http://dx.doi.org/10.1080/00224491003605475

Cochran, J. K., Chamlin, M. B., Beeghley, L., \& Fenwick, M. (2004). Religion, Religiosity, and Nonmarital Sexual Conduct: An Application of Reference Group Theory. Sociology Inquiry, 74, 102-127.

http://dx.doi.org/10.1111/j.1475-682X.2004.00081.x

Crockett, L., Bingham, R., Chopak, J., \& Vicary, J. (1996). Timing of First Sexual Intercourse: The Role of Social Control, Social Learning, and Problem Behavior. Journal of Youth and Adolescence, 25, 89-111. http://dx.doi.org/10.1007/BF01537382

Davis, L., \& Poctor, E. (1989). Race, Gender and Class: Guidelines for Practice with Individuals, Families and Groups. Englewood Cliffs, NJ: Prentice Hall.

Falicov, C. (1983). Cultural Perspectives in Family Therapy. Rockville, MD: Aspen. 
Falicov, C. (1998). Latino Families in Therapy. New York: Guilford Press.

Friedman, D. (2001). A Mind of Its Own: A Cultural History of the Penis. London: Penguin.

Ghana Population Census (2010). Statistical Service. Accra: Ministries.

Glassner, B., \& Owen, W. (1979). Variation in Attitudes towards Homosexuals. Cornell Journal of Social Relations, 11, 161-176.

Herek, G. (1984). Beyond "Homophobia”: A Social Psychological Perspective on Attitudes towards Lesbians and Gay Men. In J. P. DeCocco (Ed.), Homophobia: An Overview (pp. 1-21). New York: Haworth Press. http://dx.doi.org/10.1300/j082v10n01_01

Hinchliff, S., Gott, M., \& Galena, E. (2005). “I Daresay I Might Find It Embarrassing”: General Practitioners’ Perspectives on Discussing Sexual Health Issues with Lesbian and Gay Patients. Health \& Social Care in the Community, 13, $345-353$. http://dx.doi.org/10.1111/j.1365-2524.2005.00566.x

Horowitz, S. M., Weis, D. L., \& Laflin, M. T. (2001). Differences between Sexual Orientation Behavior Groups and Social Background, Quality of Life, and Health Behaviors. Journal of Sex Research, 38, 205-218. http://dx.doi.org/10.1080/00224490109552089

Kan, R. W. M., Au, K. P., Chan, W. K., Cheung, L. W. M., Lam, C. Y. Y., Liu, H. H. W. et al. (2009). Homophobia in Medical Students of the University of Hong Kong. Sex Education, 9, 65-80. http://dx.doi.org/10.1080/14681810802639848

Kimmel, S. B., \& Mahalik, J. R. (1987). Body Image Concerns of Gay Men: The Roles of Minority Stress and Conformity to Masculine Norms. Journal of Consulting and Clinical Psychology, 73, 1185-1190. http://dx.doi.org/10.1037/0022-006X.73.6.1185

Kuyper, L., \& Vanwesenbeeck, I. (2003). Examining Sexual Health Differences between Lesbians, Gay, Bisexual, and Heterosexual Adults: The Role of Socio-Demographics, Sexual Behavior Characteristics, and Minority Stress. Journal of Sex Research, 48, 263-274.

Leiber, J. (2006). Instinctive Incest Avoidance: A Paradigm Case for Evolutionary Psychology Evaporates. Journal for the Theory of Social Behavior, 36, 369-388. http://dx.doi.org/10.1111/j.1468-5914.2006.00313.x

Lumby, M. E. (1976). Homophobia: The Quest for a Valid Scale. Journal of Homosexuality, 2, 39-46. http://dx.doi.org/10.1300/J082v02n01_04

McFarland, M. J., Uecker, J. E., \& Regnerus, M. D. (2011). The Role of Religion in Shaping Sexual Frequency and Satisfaction: Evidence from Married and Unmarried Older Adults. Journal of Sex Research, 48, 297-308. http://dx.doi.org/10.1080/00224491003739993

McFarlane, L. (1998). Diagnosis: Homophobic: The Experiences of Lesbians, Gay Men and Bisexuals in Mental Health Services. London: PACE: The Project for Advice, Counseling and Education.

McGoldrick, M., Giordano, J., \& Pearce, J. (1996). Ethnicity and Family Therapy (2nd ed.). New York: Guilford Press.

Milham, J., San Miguel, C., \& Kellog, R. (1976). A Factor-Analytic Conceptualization of Attitude toward Male and Female Homosexual. Journal of Homosexuality, 2, 3-10. http://dx.doi.org/10.1300/J082v02n01_01

Minuchin, S., Montalvo, B., Guerney, B., Rosman, B., \& Schumer, F. (1967). Families of the Slums. New York: Basic Books.

Ninsin, K. A. (2007). Markets and the Liberal Democracy. In K. Baofo-Arthur (Ed.), Ghana: One Decade of the Liberal State (pp. 11-31). Dakar: CODESRIA.

Norman, I. D. (2005). Love, Lust \& Lies. Accra: Infinity Press.

Norman, I. D., Aikins, M., \& Binka, F. N. (2011). Traditional and Contrapower Sexual Harassment in Public Universities and Professional Training Institutions of Ghana. Manuscript Submitted for Publication.

Nyberg, K., \& Alston, J. P. (1976). Analysis of Public Attitudes towards Homosexual Behavior. Journal of Homosexuality, 2, 99-107. http://dx.doi.org/10.1300/J082v02n02_01

Okun, B. (1996). Understanding Diverse Families. New York: Guilford Press.

Osei, A. (2011). Homosexuality, to Legalize or Not? Accra: Adabraka Psychiatric Hospital.

Ozbay, C. (2010). Nocturnal Queers: Rent Boys’ Masculinity in Istanbul. Journal of Sexualities, 13, 645-664. http://dx.doi.org/10.1177/1363460710376489

Parker, A., \& Bhugra, D. (2000). Attitudes of British Medical Students towards Male Homosexuality. Sexual and Relationship Therapy, 15, 141-149. http://dx.doi.org/10.1080/14681990050010736

Pinderhughes, E. (1989). Understanding Race, Ethnicity and Power: The Key to Efficacy in Clinical Practice. New York: Basic Books. 
Pleck, J. H., Sonenstein, F. L., \& Ku, L. C. (1993). Masculinity Ideology: Its Impact on Adolescent Males’ Heterosexual Relationships. Journal of Social Issues, 49, 11-29. http://dx.doi.org/10.1111/j.1540-4560.1993.tb01166.x

Rose, L. (1994). Homophobia among Doctors. British Medical Journal, 308, 586-587. http://dx.doi.org/10.1136/bmj.308.6928.586

Smith, H., \& Israel, E. (1987). Sibling Incest: A Study of the Dynamics of 25 Cases. Child Abuse and Neglect, 11, $101-108$. http://dx.doi.org/10.1016/0145-2134(87)90038-X

Valleroy, L. A., MacKellar, D. A., Rosen, D. H., McFarland, W., Shehan, D. A. et al. (2000). HIV Prevalence and Associated Risks in Young Men Who Have Sex with Men. Journal of the American Medical Association, 284, 198-204. http://dx.doi.org/10.1001/jama.284.2.198

Vaughan, M. (1991). Curing Their Ills: Colonial Power and African Illness. Cambridge: Polity Press.

World Health Organization (2006). Defining Sexual Health: Report of a Technical Consultation on Sexual Health, 28-31 January 2002. Geneva: World Health Organization.

Yamba, B. (2004). The Wailing Song of Male Sexuality: A Valedictory Note on African Masculinity, Sexuality and Maleness in the Times of AIDs (pp. 5-7). Uppsala: Nordic Africa Institute. 


\section{Appendix}

STROBE Statement—Checklist of items that should be included in reports of cross-sectional studies.

\section{Item No. Recommendation}

Homosexuality in Ghana (Page 4).

This paper investigated the incidence and prevalence of homosexuality and lesbianism in Ghana. Assessment was done on association between psychosocial background, sexual attitudes and

Title and abstract homosexuality; including the use of paraphernalia in the sexual lives of the people. The study revealed that the national attitudes towards homosexuality in general are changing from ambivalence to focused activism and agitation against homosexuality on one hand and acceptance on the other hand. Homosexuality and lesbian practices are prevalent in all socio-economic classes and ages of society (Page 2).

Introduction

Explain the scientific background

Background/rationale 2 The rationale for conducting this research is that, homosexuality is a crime in Ghana yet, it is observed to be still practiced among all social classes of individuals in the population, yet these practitioners are not able to openly declare their sexual orientation because of the fear of opposition and agitation (Page 4).

Objectives $\quad 3 \quad \begin{aligned} & \text { This paper investigated the incidence and prevalence of homosexuality and lesbianism in Ghal } \\ & \text { Assessment was done on association between psychosocial background, sexual attitudes and }\end{aligned}$ homosexuality; including the use of paraphernalia in the sexual lives of the people (Page 7).

\begin{tabular}{|c|c|c|}
\hline Tethods & & \\
\hline Study design & 4 & $\begin{array}{l}\text { Present key elements of study design early in the paper } \\
\text { This is a cross-sectional study. It consisted of questionnaire survey, desktop and internet review (Page 7). }\end{array}$ \\
\hline Setting & 5 & $\begin{array}{l}\text { Describe the setting, locations, and relevant dates, including periods of recruitment, exposure, } \\
\text { follow-up, and data collection } \\
\text { The study targeted the general population of Ghana but looked at only people who were at least } 16 \text { years } \\
\text { old. The study was purely exploratory and did not test any hypothesis (Page 7). }\end{array}$ \\
\hline Participants & 6 & $\begin{array}{l}\text { a) Give the eligibility criteria, and the sources and methods of selection of participants } \\
\text { The study targeted the general population of Ghana but looked at only people who were at least } 16 \text { years } \\
\text { old (Page 7). }\end{array}$ \\
\hline Variables & 7 & N/A \\
\hline $\begin{array}{l}\text { Data } \\
\text { sources/measurement }\end{array}$ & $8^{*}$ & $\begin{array}{l}\text { For each variable of interest, give sources of data and details of methods of assessment } \\
\text { (measurement) } \\
\text { Obviously each variable of interest came from the questionnaire used and measured appropriately. The } \\
\text { attachment might help with this. } \\
\text { Describe comparability of assessment methods if there is more than one group } \\
\text { Chi-square tests were used to compare categorical variables initially for independence or homogeneity; } \\
\text { continuous variables like age were categorized into age ranges for this. Logistic regression was further } \\
\text { used to compare unadjusted odds ratios where the Chi-square test results were significant. }\end{array}$ \\
\hline Bias & 9 & $\begin{array}{l}\text { Describe any efforts to address potential sources of bias } \\
\text { Due to the sensitive nature of the study, respondents were interviewed out of their homes (Page 7). }\end{array}$ \\
\hline Study size & 10 & $\begin{array}{l}\text { Explain how the study size was arrived at } \\
\text { The sample consisted of }(\mathrm{N}=1068) \text { respondents. Sampling selection was of random, pre-stratified by } \\
\text { gender and region, which was based on the population survey by the Ghana Statistical Service for } 2009 \\
\text { (Page 8). }\end{array}$ \\
\hline Quantitative variables & 11 & $\begin{array}{l}\text { Explain how quantitative variables were handled in the analyses. If applicable, describe which } \\
\text { groupings were chosen and why } \\
\text { Data entry was done using the Statistical Package for Social Sciences (SPSS). Descriptive and exploratory } \\
\text { analyses were carried out using SPSS to assess if there are trends in the sexual mores of a conventional } \\
\text { society (Ghana); and to assess if there is association between psychosocial background and sexual } \\
\text { attitudes. Analyses were also carried out to find the demographic characteristics of respondents as well as } \\
\text { their sexual attitudes and behaviors. Further analyses using SPSS and STATA (Chi-square tests and } \\
\text { logistic regression methods) were also carried out to explore if there were associations between } \\
\text { respondents' background, sexual behaviours and orientation (Page 8). }\end{array}$ \\
\hline
\end{tabular}




\section{Continued}

\begin{tabular}{ll}
\hline & N/A \\
N/A & a) Explain how missing data were addressed \\
Missing data were excluded from each analysis, hence the use of subtotals with varying values.
\end{tabular}

N/A

Results

$\begin{array}{ll} & \begin{array}{l}\text { a) Report numbers of individuals at each stage of study-e.g. numbers potentially eligible, examined } \\ \text { for eligibility, confirmed eligible, included in the study, completing follow-up, and analyzed } \\ \text { The return rate was a hundred percent although not all the questions were answered by all the respondents }\end{array} \\ \text { Participants } & 13^{*} \quad \begin{array}{l}\text { (Page 19). }\end{array}\end{array}$

N/A

N/A

a) Give characteristics of study participants (eg demographic, clinical, social) and information on exposures and potential confounders

The response rate to the questionnaire developed for this purpose was 974/1068 (91.2\%). This may be Descriptive data $\quad 14^{*} \quad$ attributable to those who decline to associate with a particular age group or perhaps did not know their correct ages. There were 484 females and the rest were males (Page 9).

b) Indicate number of participants with missing data for each variable of interest See attachment

Report numbers of outcome events or summary measures

Outcome data $\quad 15^{*} \quad$ The respective Chi-square tables show this and should be used in conjunction with the logistic regression table.

a) Give unadjusted estimates and, if applicable, confounder-adjusted estimates and their precision (e.g., 95\% confidence interval). Make clear which confounders were adjusted for and why they were included

The logistic regression models were unadjusted and confounders not taken into account.

Main results

b) Report category boundaries when continuous variables were categorized.

This was done for age (years) as follows:

16-20, 21-25, 26-30, 31-35, 36-40, 41-45, 46 and over.

c) If relevant, consider translating estimates of relative risk into absolute risk for a meaningful time period

Relative odds were used instead of risk in the study.

Other analyses $\quad 17 \quad$ Report other analyses done- e.g. analyses of subgroups and interactions, and sensitivity analyses These were not done.

Discussion $\quad$ Summarise key results with reference to study objectives

About $27 \%$ of the respondents have had either anal sex or have had homosexual experience before.

Key results

The curiosity of Ghanaians in sex appears to be quite extensive. They seem ready to try multiple configurations of sexual activities, including having sex with multiple partners, (ménage-a-trois) at the same time. More than $24 \%$ of the males and (19\%) of the females said they would like to try to have sex with three, four or five persons at the same time (Page 9).

Discuss limitations of the study, taking into account sources of potential bias or imprecision. In looking at the sexual habits of people, it is difficult to audit the true nature of the information provided by respondents. As far as Ghana is concerned, this is the first of its kind where a cross-sectional study of this nature has been carried out (page 19).

Limitations

Discuss both direction and magnitude of any potential bias

Admittedly, the sample could be biased. The return rate was a hundred percent although not all the questions were answered by all the respondents. This could be attributable to the youthfulness of the research assistants, who established a rapport with the respondents.

Due to the self-reporting nature of the questionnaire administered, it is possible that respondents might not be truthful, or have difficulty in expressing the true nature of their sexual proclivities and thus leading to poor characterization (page 19). 


\section{Continued}

\begin{tabular}{ll}
\hline & $\begin{array}{l}\text { Give a cautious overall interpretation of results considering objectives, limitations, multiplicity of } \\
\text { analyses, results from similar studies, and other relevant evidence } \\
\text { From the study, the national attitudes towards homosexuality in general are changing from ambivalence to } \\
\text { focused activism and agitation against homosexuality on one hand and acceptance on the other hand. }\end{array}$ \\
$\begin{array}{ll}\text { Interpretation } \\
\text { Homosexuality and lesbian practices are prevalent in all socio-economic classes and ages of society. The } \\
\text { study revealed that pornography and other sex media are accepted as part of the sexual repertoire of } \\
\text { Ghanaian society. } \\
\text { This is confirmed by findings by Parker \& Bhugra (2000), which indicated that, there are homophobic } \\
\text { tendencies among medical professionals, and the fact that communication between patients and doctors are } \\
\text { strained in the face of HIV and AIDs (pages } 4 \text { and16). } \\
\text { Discuss the generalisability (external validity) of the study results. }\end{array}$ \\
$\begin{array}{l}\text { Generalisability } \\
\text { Other information }\end{array}$ \\
$\begin{array}{l}\text { Funding } \\
22\end{array}$
\end{tabular}

